\title{
ROLE OF THE STATE IN IMPROVING THE LIVING STANDARDS OF HOUSEHOLDS
}

\author{
Karnaushenko A. S., Petrenko V. S.
}

\section{INTRODUCTION}

Each country should strive for more full satisfaction of the needs of its citizens. However, in reality, the most vulnerable remain existential needs, namely the need for security of human life, which are realised through comfort, stability of living conditions, security of existence and confidence in the future. These needs are basic in their nature and form a sustainable basis for the development of a country's economy and society in general. The issues of improving the living standards of households do not lose its relevance, since they are the most important component of the economy of a modern country. A significant drop in the material well-being of a large part of Ukraine's population has caused an intense economic stratification of society.

Thus, the problems of improving households' living standards are important today both for the citizens themselves and for the Ukrainian government. The strategic development priorities of Ukraine determine the need for state intervention and regulation of issues related to the improvement of living standards at the national, regional and territorial levels.

The current state of the economy of any country in the world is characterised primarily by the level and quality of life of its population. "The standard of living of a population determines the extent to which a country's citizens or residents of a particular region are supplied with material goods, services and opportunities and are financially and spiritually satisfied with the amount of goods, services and opportunities available to them in a given period".

The standard of living, in a narrow sense, is a system of quantitative indicators characterising resource provision and satisfaction of needs (income of the average person, the amount of his/her expenditure on purchases, payment for services, etc.). The reason for this approach is that the assessment of the benefits to be applied is directly quantifiable.

\section{Socio-economic development of Ukraine}

At present, Ukraine is experiencing modest growth in some economic sectors (e.g., retail and construction) as the government introduces certain measures to overcome the crisis. In general, the standard of living in the country is gradually improving and tends to return to its pre-crisis state, but is 
most likely to do so once COVID-19 has been overcome ${ }^{1}$. According to the State Statistics Service of Ukraine ${ }^{2}(2021)$, the country's socio-economic indicators for the first 9 months of 2020 show an upward trend compared to the same period last year (Table 1).

Table 1

Socio-economic indicators of Ukraine's development

\begin{tabular}{|c|c|c|c|c|c|}
\hline \multirow{3}{*}{ Indicators } & \multirow{3}{*}{$\begin{array}{c}\text { Actually } \\
\text { for } \\
\text { January- } \\
\text { September } \\
\mathbf{2 0 2 0}\end{array}$} & \multicolumn{4}{|c|}{ Rate of growth (decline), $\%$} \\
\hline & & \multicolumn{2}{|c|}{$\begin{array}{l}\text { September } \\
2020 \text { till }\end{array}$} & \multirow{2}{*}{\begin{tabular}{|c} 
January - \\
September \\
2020 till \\
January - \\
September \\
2019
\end{tabular}} & \multirow{2}{*}{$\begin{array}{c}\text { January - } \\
\text { September } \\
2019 \text { till } \\
\text { January - } \\
\text { September } \\
2018\end{array}$} \\
\hline & & $\begin{array}{c}\text { August } \\
\mathbf{2 0 2 0}\end{array}$ & $\begin{array}{l}\text { September } \\
2019\end{array}$ & & \\
\hline 1 & 2 & 3 & 4 & 5 & 6 \\
\hline $\begin{array}{l}\text { Average monthly } \\
\text { wage per } \\
\text { employee: } \\
\text { nominal, UAH }\end{array}$ & 11199 & 104.8 & 112.3 & 109.2 & 119.2 \\
\hline actual, $\%$ & $\times$ & 104.3 & 109.7 & 106.6 & 109.5 \\
\hline $\begin{array}{l}\text { Arrears in wages - } \\
\text { total, UAH million }\end{array}$ & $3,560.9$ & 104.1 & 113.4 & $x$ & 108.7 \\
\hline $\begin{array}{l}\text { Consumer price } \\
\text { index }\end{array}$ & $\times$ & 100.5 & 102.3 & 102.4 & 108.8 \\
\hline $\begin{array}{l}\text { Price index of } \\
\text { industrial } \\
\text { manufacturers }\end{array}$ & $\times$ & 101.7 & 98.3 & 95.2 & 106.9 \\
\hline $\begin{array}{l}\text { Industrial } \\
\text { production index }\end{array}$ & $\times$ & 104.5 & 95.6 & 93 & 101.2 \\
\hline $\begin{array}{l}\text { Agricultural } \\
\text { production index }\end{array}$ & $\times$ & 186.9 & 80.8 & 86.9 & 106,5 \\
\hline \begin{tabular}{|l|} 
Construction \\
product index
\end{tabular} & $\times$ & 118.3 & 112.5 & 100.2 & 123.5 \\
\hline
\end{tabular}

${ }^{1}$ Chervona, S. (2020). COVID-19 ta yoho vplyv na riven zhyttia naselennia Ukrainy [COVID-19 and its impact on the living standards of the population of Ukraine]. Stratehiia rozvytku Ukrainy: finansovo-ekonomichnyi ta humanitarnyi aspekty : materialy VII Mizhnarodnoi naukovo-praktychnoi konferentsii. 400-403.

${ }^{2}$ State Statistics Service of Ukraine (2020), from http://www.ukrstat.gov.ua/ 
Table 1 (ending)

\begin{tabular}{|l|c|c|c|c|c|}
\hline \multicolumn{1}{|c|}{1} & 2 & 3 & 4 & 5 & 6 \\
\hline $\begin{array}{l}\text { Exports of goods, } \\
\text { USD million }\end{array}$ & $30,842.9$ & 113.3 & 98.4 & 93.4 & 106.9 \\
\hline $\begin{array}{l}\text { Imports of goods, } \\
\text { USD million }\end{array}$ & $33,241.6^{2}$ & $98.8^{3}$ & $85.7^{4}$ & $85.4^{2}$ & $108.4^{2}$ \\
\hline $\begin{array}{l}\text { Balance (+, -), } \\
\text { USD million }\end{array}$ & $-2,398.7$ & $\times$ & $\times$ & $\times$ & $\times$ \\
\hline $\begin{array}{l}\text { Retail turnover, } \\
\text { UAH million }\end{array}$ & $854,148.8$ & 99.3 & 111.6 & 106.7 & 110.0 \\
\hline $\begin{array}{l}\text { Freight turnover, } \\
\text { mln. tonne- } \\
\text { kilometres }\end{array}$ & $210,713.3$ & 95.6 & 87.3 & 83.4 & 101.9 \\
\hline $\begin{array}{l}\text { Passenger traffic, } \\
\text { mln. passenger- } \\
\text { kilometres }\end{array}$ & $37,053.3$ & 93.8 & 50.5 & 45.6 & 103.0 \\
\hline
\end{tabular}

Analysis of Table 1 shows that the average monthly wage of an employee during 9 months of 2020 has increased by $12.3 \%$ compared to the same period last year, the construction product index has also increased by $12.5 \%$, and retail trade turnover has grown by $11.6 \%$. The following indicators reduced volumes as follows: Price index of industrial manufacturers - by $1.7 \%$, industrial production index - by $4.4 \%$, agricultural production index - by $19.2 \%$, exports of goods - by $1.6 \%$, imports of goods - by $14.3 \%$, freight turnover - by $12.7 \%$, passenger traffic - by $49.5 \%$. But in Table 1 there are indicators of an increase that have a negative impact on the socio-economic development of the country - arrears in wages, which increased by $13.4 \%$ (3,560.9 UAH million arrears occurred in 9 months of 2020) and the consumer price index, which increased by $2.3 \%$.

\section{Level of the Human Development Index in Ukraine}

The state of a country's socio-economic development has a direct impact on the level of the Human Development Index. Every year, the UN determines the level of the Human Development Index ${ }^{3}$; so in 2019, Norway, Switzerland and Ireland topped the world ranking for this indicator, which is often referred to as the world ranking for living standards. The data were presented in the UN's annual Human Development Report 2019. "The Human Development Index is a composite indicator measuring human development in countries and

${ }^{3}$ Human Development Report. (2020). Electronic resources Retrieved, December 15, 2020 from http://hdr.undp.org/en/content/2020-human-development-report-next-frontierhuman-development-and-anthropocene 
regions of the world". This indicator is identified with concepts such as "quality of life" or "standard of living".

The index measures a country's achievements in terms of health, educational attainment and actual income of citizens, in three main areas: access to education, health and longevity and a decent standard of living. When analysing the annual totals of the country rankings for this index, we can see significant changes. Indeed, in assessing previous years' leaders, it is established that the top three states change every year ${ }^{4}$. For example, in 2018 the top three were Norway, Switzerland and Australia. And in 2019, Australia was pushed aside by Ireland to take third place. Ukraine's place in the ranking of countries of the world in terms of living standards of the population ranks around $88^{\text {th }}$ place ${ }^{5}$. For example, Ukraine ranked $88^{\text {th }}$ in the 2014 ranking, but in the last couple of years it has consolidated its position at $85^{\text {th }}$.

For objectivity in determining the low level of the human development index in Ukraine, it is worth comparing the parameters of Ukraine and the leader of the ranking, Norway. This comparison will help to understand how far Ukraine lags behind the leaders of this ranking (Table 2).

When analysing table 2, we observe disappointing results in Ukraine, especially regarding the expectation of life at birth, the difference between Ukraine and Norway is 14.3 years. When comparing the Ukrainian gross national income per capita to that of Norway, it is found to be almost $50 \%$ lower than in Norway (fig. 1).

Table 2

Comparison of Ukraine's and Norway's Human Development Index indicators

\begin{tabular}{|c|l|c|c|}
\hline $\begin{array}{c}\text { Pos. } \\
\text { No. }\end{array}$ & \multicolumn{1}{|c|}{ Indicator } & Ukraine & Norway \\
\hline 1 & Ranking position & 83 & 1 \\
\hline 2 & Human development index & 0.750 & 0.954 \\
\hline 3 & Expectation of life at birth, years & 68 & 82.3 \\
\hline 4 & Gross national income (GNI) per capita & 36.59 & 68.059 \\
\hline 5 & Expected years of education, years & 17 & 18.1 \\
\hline 6 & Average years of education, years & 12 & 12.6 \\
\hline
\end{tabular}

${ }^{4}$ Reyting stran mira po urovnyu Valovogo vnutrennego produkta [Rating of countries in the world by the level of Gross Domestic Product.] (2020). Humanitarnyy portal. URL: https://gtmarket.ru/ratings/rating-countries-gdp/rating-countries-gdp-info

${ }^{5}$ Mesto pod solntsem: Top-20 ekonomik mira [A place in the sun: Top 20 economies in the world.] (2020). Faktograf. URL: https://www.factograph.info/a/30825544.html 


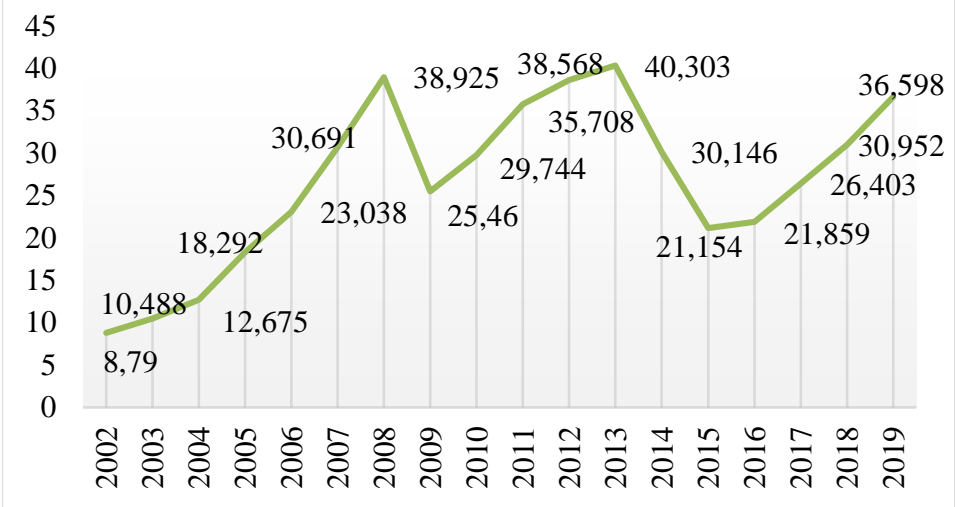

\section{Fig. 1. Value of nominal GDP per capita in Ukraine for the period 2002-2019, USD}

When analysing Figure 1, we can conclude that nominal GDP per capita is very volatile, with major declines in 2008-2009 and 2013-2014 due to the global crisis in 2008 and the dignity revolution in 2013 and the start of the anti-terrorist operation in eastern Ukraine in 2014. It is recognized that the GDP in the country is also contracting due to a reduction in the number of entrepreneurs who are liquidating their businesses and moving into the shadow economy to save on taxes, which is undoubtedly worsening the situation (Reyting stran mira po urovnyu, 2020).

The International Labour Organisation Convention states that "everyone has the right to a standard of living (including food, clothing, housing and medical care and social services) adequate for the health and well-being of himself and his family, and the right to security in the event of unemployment, incapacity for work or loss of breadwinner". Each country implements the above rights based on its own national strategy for improving living standards.

Based on the Constitution of Ukraine and Article 48, which states that "everyone has the right to an adequate standard of living for himself and his family, including adequate food, clothing and housing", it can be argued that the country has an unequal distribution of population into poor and rich, but if we consider the examples of developed countries, it is the middle class that forms the basis for the innovative development of the economy ${ }^{6}$.

${ }^{6}$ Borovik, L. (2018). Analiz vplyvu domohospodarstv naselennia na investytsiinu pryvablyvist haluzi [Analysis of the impact of households on the investment attractiveness of the industry]. Problemy systemnoho pidkhodu v ekonomitsi, 4(66), 33-38. 


\section{Poverty rate in Ukraine}

An analysis of the poverty rate in Ukraine for the first quarter (Q1) of 2020 reveals a significant increase in this indicator (Minimalna zarobitna plata, 2020). Thus, the expenditure poverty rate is significantly lower than the real living wage - it has increased by $5.7 \%$ compared to the first quarter of 2019 , and the income poverty rate is $2.8 \%$ lower than the living wage. The absolute poverty rate rose by $0.1 \%$ to $2.9 \%$. Assessing the poverty rate by the UN international benchmark, a decrease by $0.9 \%$ was found (Fig. 2).

For Q1 2020, the relative poverty rate remained at the same level as Q1 2019 , at $25.4 \%$, and decreased by 0.1 percentage points to $12.8 \%$ by the criterion using the EU equivalent scale ( $60 \%$ of total income median).

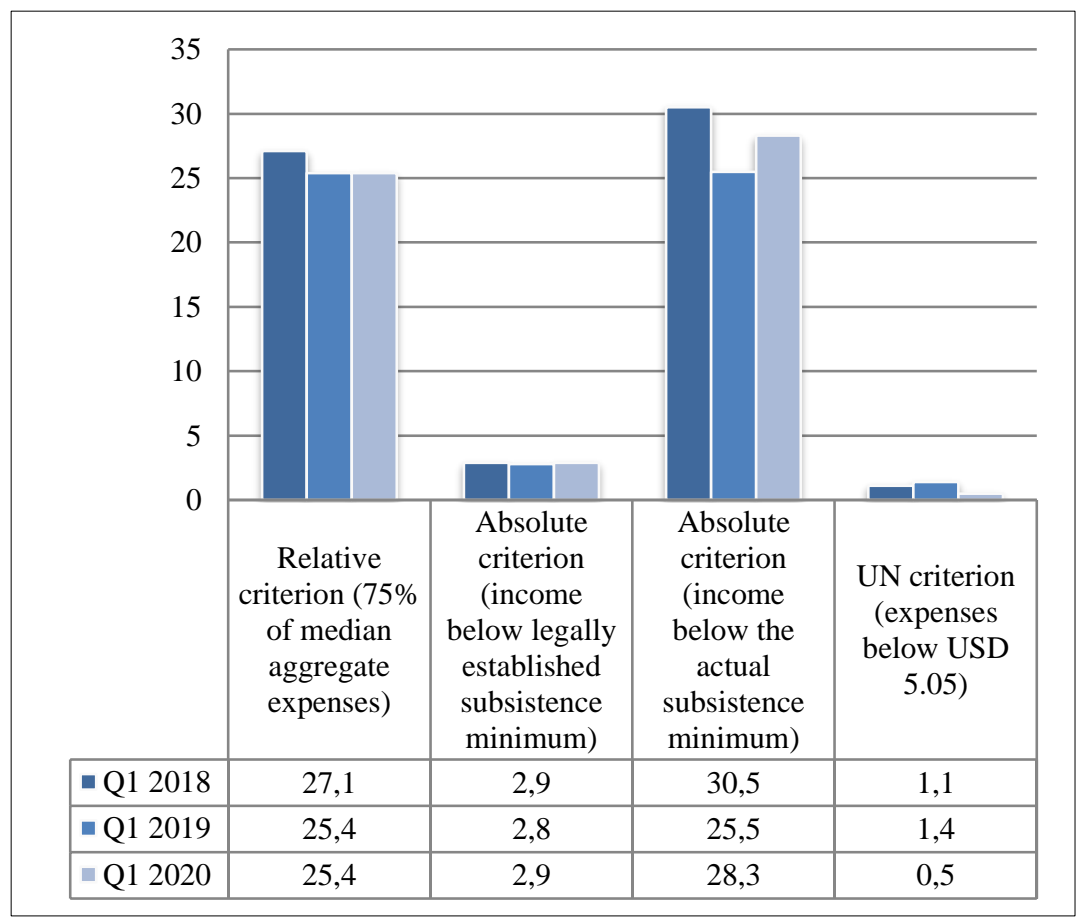

Fig. 2. Poverty rates by different criteria, $\%$

In view of the above data on poverty indicators, it is advisable to consider them in terms of socio-demographic groups (Figure 3): poverty rate among the working population; poverty rate among persons of pension age; poverty rate among children aged $0-17$; poverty rate among persons aged 16-19. 


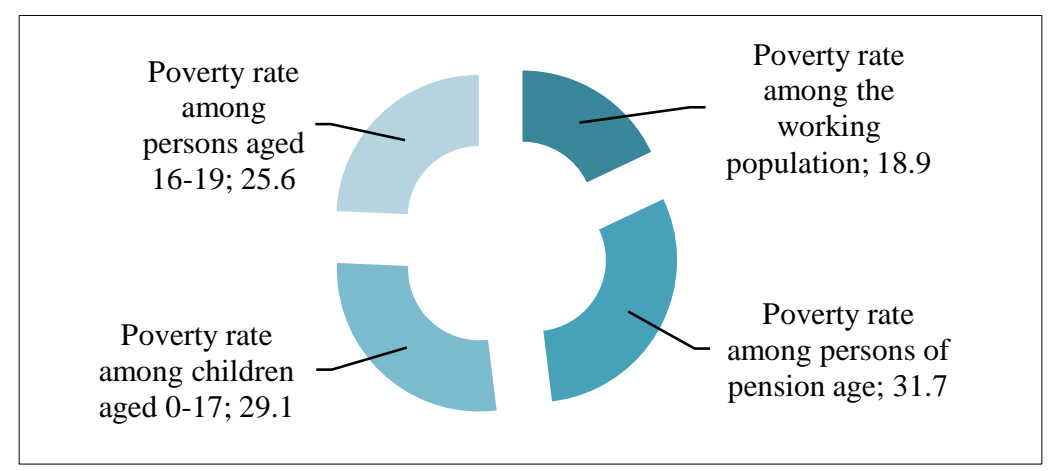

\section{Fig. 3. Percentage of poverty in the breakdown of social and demographic groups in the first quarter of $2020, \%$}

When analysing Figure 3, it has been established that the most vulnerable segments of the population are children aged 0-17 and pensioners, 29.1 and 31.7 respectively, i.e. every third pensioner and every third child lives in poverty.

Considering the above, it has been established that today's Ukraine must develop only if its economic policy is directed at improving the living standards of its people and opening up greater opportunities for the organization of its own future ${ }^{7}$. To this end, priority should be given not only to increasing the minimum wage but also to improving other components of the "standard of living" indicator, namely: maintaining true equality for education and employment; ensuring gender equality for men and women; ensuring a high level of health services; quality nutrition ${ }^{8}$, etc.

\section{Level of state support for households}

The social services system is a crucial category for the different components of quality of life, the importance and role of which can significantly influence perceptions of consumer opportunities. However, the

${ }^{7}$ Karnaushenko, A., Petrenko, V., Tanklevska, N., Borovik, L., \& Furdak, M. (2020). Prospects of youth agricultural entrepreneurship in Ukraine. Agricultural and Resource Economics: International Scientific E-Journal, 6(4), 90-117. URL: https://doi.org/ 10.51599/are.2020.06.04.06

${ }^{8}$ Hetman, A. \& Boyko, L. (2019). Sotsialno-ekonomichni problemy silskykh zhinok na suchasnomu etapi [Socio-economic problems of rural women at the present stage]. Ekonomichnyy rozvytok Ukrayiny $v$ konteksti vprovadzhennya prohresyvnykh informatsiynykh tekhnolohiy ta system upravlinnya: materialy II Vseukr. nauk.-prakt. konf., Kyiv, 214-217. 
disadvantaged population takes such state aid for granted, without appreciating how much they ultimately cost to society and how much each citizen receives in the form of free services and benefits in addition to the income received from various sources. Furthermore, it leads to a distortion of both state and inter-state comparisons.

Thus, within the framework of a comprehensive analysis of the standard of living of households, it is worth investigating the system of state minimum social guarantees in the implementation of state social policy, including the services whose provision (at the expense of budgets of all levels, as well as state non-budgetary funds) is guaranteed to citizens under the regulatory and legal acts.

The basic minimum social standards that regulate the income sphere on the part of the state are the subsistence minimum and the minimum wage. In the area of pension provisions, the guarantees include a statutory minimum amount of pensions. State minimum guarantees in the area of social security are state assistance for unemployment, benefits for families with many children, social assistance for low-income persons ${ }^{9}$, etc.

One of the important indicators of the standard of living of the population is also the volume and quality of consumption of socio-cultural services and an assessment of the state of the relevant sectors. At the same time, it should be taken into account that the population receives almost free medical care, preschool, general, vocational and higher education, assistance to large families, the disabled and other vulnerable categories of persons (free or partially paid medicine, school lunches), and social services that provide the complex of living conditions of people (tariff policy in passenger transport and benefits in the housing and communal services segment).

When implementing social policy by providing social support measures to the population, mechanisms are used ${ }^{10}$, such as:

- guarantees - activities to implement this or that provision (e.g. approval of social standards, protection against unemployment);

- compensation - reimbursement of losses caused by reasons for which the state assumes responsibility, as well as monetary payments assigned to citizens in order to provide additional material support in cases recognized by the state as socially significant, related to compensation for loss (reduction) of

${ }^{9}$ Advokatova, N. (2017). Faktory vplyvu mihratsiyi robochoyi syly Ukrayiny v umovakh yevropeys'koyi intehratsiyi [Factorial impact of Ukrainian labor migration in the context of European integration]. Ekonomichni innovatsiyi: Zbirnyk naukovykh prats, $64,12-17$.

${ }^{10}$ Derzhavne rehuliuvannia rivnia ta yakosti zhyttia naselennia [State regulation of the level and quality of life of the population] (2020). Biblioteka ekonomista. URL: https://library.if.ua/book/72/5283.html 
income (e.g. family members of a deceased military serviceman; compensation payments for expenses on housing, utilities and other services; payments for childcare leave, payments for children under guardianship and custody; payments to non-working persons capable of working who care for incapacitated citizens)

- benefits - a preference, partial exemption from or provision of conditions for the fulfilment of established rules, duties or obligations. Benefits are a separate part of social security and deal with the protection of the most vulnerable population groups. It is the most widespread and ramified element of the social support system, including benefits for transport, housing and communal services, education, medical care, etc.

Persons who have rendered distinguished service to their country are entitled to benefits: persons awarded orders and medals, war and labour veterans, veterans of combat operations, citizens who took part in the cleanup of man-made disasters; pensioners, persons with disabilities, children without parental care, etc.

Thus, social benefits and services are diverse. They are differentiated by means of financing, number of beneficiaries, and conditions of provision. All social transfers can be of one-time nature or be paid periodically over a set period of time. Social benefits can take the form of tax exemptions.

Ukraine's current system of social services is inherited from the Soviet Union. Moreover, the transition to a market economy requires the authorities to strengthen this component with budget financing possibilities and to increase the role of citizens in ensuring personal welfare and well-being in modern conditions. The decline in production, the rise in unemployment and forced labour migration have exacerbated social aspects of life. In the context of the transition to a market economy and given the situation in the world at the height of the pandemic, the material situation of many citizens has deteriorated markedly, necessitating an expansion of the list of preferences available to socially vulnerable categories of the population. This process will continue until the COVID-19 pandemic is overcome.

In some cases, benefits are an additional incentive to attract workers to different types of activities or under certain conditions (benefits to attract labour to industries with difficult and hazardous working conditions, as well as to social institutions (education, medicine, social protection) located in rural areas, etc.

Various social support measures (which include benefits, allowances and compensations) are provided to about 30 categories of citizens. The number of persons receiving benefits (veterans, disabled persons, pensioners, large families, students, unemployed persons, children without parental care, persons receiving occupational benefits, etc.) amounts to almost one third of the total population of Ukraine (Table 3). 
Table 3

Number of persons receiving social assistance and its average amount

\begin{tabular}{|c|c|c|c|c|c|c|c|}
\hline \multirow[t]{2}{*}{$\begin{array}{l}\text { Pos. } \\
\text { No. }\end{array}$} & \multirow[t]{2}{*}{ Name of assistance } & \multicolumn{3}{|c|}{$\begin{array}{c}\text { Number of } \\
\text { people, thousands } \\
\text { of people }\end{array}$} & \multicolumn{3}{|c|}{$\begin{array}{c}\text { Average amount } \\
\text { of assistance, UAH }\end{array}$} \\
\hline & & 2017 & 2018 & 2019 & 2017 & 2018 & 2019 \\
\hline 1 & Childbirth benefit & $1,560.9$ & $1,313.2$ & $1,143.1$ & 974 & 946 & 918 \\
\hline 2 & $\begin{array}{l}\text { Child benefit for single } \\
\text { parents }\end{array}$ & $5,538.2$ & $5,091.3$ & $4,914.7$ & 1038 & 1208 & 1333 \\
\hline 3 & $\begin{array}{l}\text { Assistance for } \\
\text { adopting a child }\end{array}$ & 2166 & 2669 & 4984 & 864 & 865 & 863 \\
\hline 4 & $\begin{array}{l}\text { Assistance for children } \\
\text { under guardianship or } \\
\text { custody }\end{array}$ & 43593 & 41568 & 39739 & 2994 & 3264 & 3555 \\
\hline 5 & $\begin{array}{l}\text { State social assistance } \\
\text { for low-income } \\
\text { families }\end{array}$ & 898.3 & 796.4 & 663.5 & 2519 & 2748 & 3019 \\
\hline 6 & $\begin{array}{l}\text { State social assistance } \\
\text { for persons disabled } \\
\text { from childhood and } \\
\text { children with } \\
\text { disabilities }\end{array}$ & 417.0 & 424.0 & 436.6 & 1962 & 2125 & 2316 \\
\hline 7 & $\begin{array}{l}\text { Temporary state } \\
\text { assistance for children } \\
\text { whose parents refuse } \\
\text { to pay maintenance } \\
\end{array}$ & 33.3 & 12.6 & 9.6 & 863 & 1114 & 1319 \\
\hline 8 & $\begin{array}{l}\text { Provision of monthly } \\
\text { assistance to persons } \\
\text { caring for persons with } \\
\text { disabilities }\end{array}$ & 56.5 & 55.6 & 56.0 & 1625 & 1815 & 1991 \\
\hline 9 & Housing subsidies & $8,809.4$ & $6,537.7$ & $5,487.9$ & 993.4 & 713 & 638.7 \\
\hline
\end{tabular}

When analysing Table 3, it was found that in 2019 the vast majority of state social assistance programmes reduced the number of payments from the state budget. The largest reductions are observed in housing subsidies, the gross value of which has decreased by more than one third compared to previous years. When analysing other social programs of the government, there has been a decrease in the number of persons receiving social support. Only in three state programs ("State social assistance for persons disabled 
from childhood and children with disabilities", "Assistance in adopting a child", "Care allowance for a person with I or II disability group due to mental disorder") there is an increase in the number of people who receive state assistance.

By analysing the above social assistance programs, it has been established that in 2019 they had a significant impact on one of the living standard indicators - the poverty rate. With the application of social assistance programs, the poverty rate decreased by $5.2-24.6 \%$. The largest impact on this indicator was the program "Assistance for Children to Single Persons", which indicates the great importance for the persons receiving these benefits.

The social programs "Assistance to low-income families" and "Assistance for Children to Single Persons" show the greatest positive impact on poverty reduction, indicating the better targeting of the programs at low-income persons and the importance of the benefits to their beneficiaries. However, a high performance indicator may indicate that these programs have a demotivating effect on those who are able to work.

According to the Law of Ukraine "On the State Budget of Ukraine in 2020 ", about 14.6 million people receive monthly social payments, including more than 11 million people who receive pensions. It can be argued that the total amount allocated by the state for social assistance in 2020 is as follows:

- the minimum maternity allowance is UAH 486,710.7 thousand per year;

- assistance for children for whom guardianship or custody has been established amounts to UAH 189684 thousand per year;

- assistance to persons disabled from childhood and children with disabilities amounts to UAH 1,101,861.48 thousand per annum;

- care allowance for a person with I or II disability group is UAH $118,984.9$ thousand per year;

- social welfare assistance amounts to UAH 53,980.7 per year, incl.:

1) benefits and housing subsidies to the population to cover the cost of housing and communal services, amount to UAH 47,628.6 mln.;

2) monthly targeted assistance to internally displaced persons to reduce living costs, including housing and utilities is UAH 3,042.6 mln.;

3) protection of the population affected by the Chernobyl catastrophe is UAH 1.980,9 mln. a year;

4) annual one-time cash assistance for war veterans and victims of Nazi persecution and social assistance for persons who have special and workrelated merits to the homeland makes UAH $1.323,7 \mathrm{mln}$. per year;

5) lifelong government scholarships amount to UAH $4.9 \mathrm{mln}$. per year;

- allowance for psychological rehabilitation of persons is UAH $116.5 \mathrm{mln}$. per year; 
- housing assistance for certain categories of the population amounts to UAH $753.6 \mathrm{mln}$. per year;

- pension payments are projected at UAH $172,576.3 \mathrm{mln}$. which is about $70 \%$ of the total accrued annual state assistance fund for social protection.

The large social payments are a burden on the state budget, which in Ukraine is in deficit and cannot meet its obligations without external assistance; on the other hand, the real average amount of most social transfers, while spending considerably on social transfers, remains very low in comparison to European Union countries. The limited budgetary resources force the state to take unpopular decisions to suspend a number of legally established benefits that have not been fulfilled for some time (e.g. the one-time program of natural childbirth assistance "Baby Package", which has been suspended since early 2020 and only became operational in summer 2020.

The rising cost of living is forcing the Ukrainian authorities to allocate more funds to social transfers. Over the ten-year period since 2010, the share of social transfers (in monetary terms) in the structure of aggregate resources of households on average per month per household income increased from UAH 12.9 to 19.3 in 2019 , and their volume in absolute terms increased by 1.4 times, while the wage fund - only 6.6 times $^{11}$ (Table 3.2).

When analysing Table 4, it is found that on average UAH 54.1 and 56.7 are accounted for by one household for 9 months 2018 and 2019 respectively for wages, and UAH 20.4 and 19.3 are accounted for by pensions, scholarships, allowances and subsidies provided in cash for 9 months 2018 and 2019 respectively. The above-mentioned indicators of wages and pensions take a key place in the structure (Figure 4).

For 9 months of 2019, the average cash income of a Ukrainian household is UAH $11,930.4-62 \%$ of total cash income; pensions, scholarships, allowances, etc. account for $21 \%$, income from entrepreneurial activity and self-employment $-7 \%$, income from the sale of agricultural products $-3 \%$. Thus, pension provision (which is based on a distribution financial mechanism) is the state's most widespread social program aimed at providing payments to the elderly population of Ukraine.

In modern society, the non-productive social sphere, including educational, health-care, cultural, artistic and social welfare institutions, plays

${ }^{11}$ Sotsialno-ekonomichne stanovyshche domohospodarstv Ukrayiny (za danymy vybirkovoho obstezhennya umov zhyttya domohospodarstv) [Socio-economic situation of households in Ukraine (according to a sample survey of living conditions of households)] (2020). State Statistics Service of Ukraine. URL: http://www.ukrstat.gov.ua/operativ/ operativ2018/gdvdg/Arh_soc_ek_stan_dom.htm 
an enormous role in human life. The Constitution of Ukraine provides for free secondary education and free use of public health facilities.

Table 4

Structure of aggregate household resources

on average per month per household

\begin{tabular}{|c|c|c|c|}
\hline Indicator & $\begin{array}{c}\text { Average } \\
\text { household } \\
\text { income } \\
\text { for } 9 \text { months } \\
\text { of } 2018 \\
\end{array}$ & $\begin{array}{c}\text { Average } \\
\text { household } \\
\text { income } \\
\text { for } 9 \text { months } \\
\text { of } 2019 \\
\end{array}$ & $\begin{array}{l}\text { Growth rate } \\
2019 \text { to } 2018\end{array}$ \\
\hline $\begin{array}{l}\text { Total aggregate resources, } \\
\text { UAH }\end{array}$ & $9,702.3$ & $11,930.4$ & 1.23 \\
\hline Cash income incl.: & 89.7 & 91.4 & 1.02 \\
\hline - wages & 54.1 & 56.7 & 1.05 \\
\hline $\begin{array}{l}\text { - Income from } \\
\text { entrepreneurial activity } \\
\text { and self-employment } \\
\end{array}$ & 5.9 & 6.4 & 1.08 \\
\hline $\begin{array}{l}\text { Income from the sale } \\
\text { of agricultural products }\end{array}$ & 2.6 & 2.5 & 0.96 \\
\hline $\begin{array}{l}\text { Pensions, grants, } \\
\text { scholarships and subsidies } \\
\text { provided in cash }\end{array}$ & 20.4 & 19.3 & 0.95 \\
\hline $\begin{array}{l}\text { monetary assistance } \\
\text { from relatives and other } \\
\text { persons }\end{array}$ & 4.0 & 3.9 & 0.98 \\
\hline - $\quad$ other cash income & 2.7 & 2.6 & 0.96 \\
\hline $\begin{array}{l}\text { Cost of products consumed } \\
\text { from private households and } \\
\text { from self-production farms }\end{array}$ & 3.6 & 3.6 & 1.00 \\
\hline $\begin{array}{l}\text { Non-cash benefits and } \\
\text { subsidies for housing } \\
\text { and communal services, } \\
\text { electricity and fuel } \\
\end{array}$ & 2.8 & 0.8 & 0.29 \\
\hline $\begin{array}{l}\text { Non-cash benefits for goods } \\
\text { and services for health care, } \\
\text { tourist services, recreational } \\
\text { facilities, etc., for transport } \\
\text { and communication services }\end{array}$ & 0.5 & 0.6 & 1.20 \\
\hline
\end{tabular}




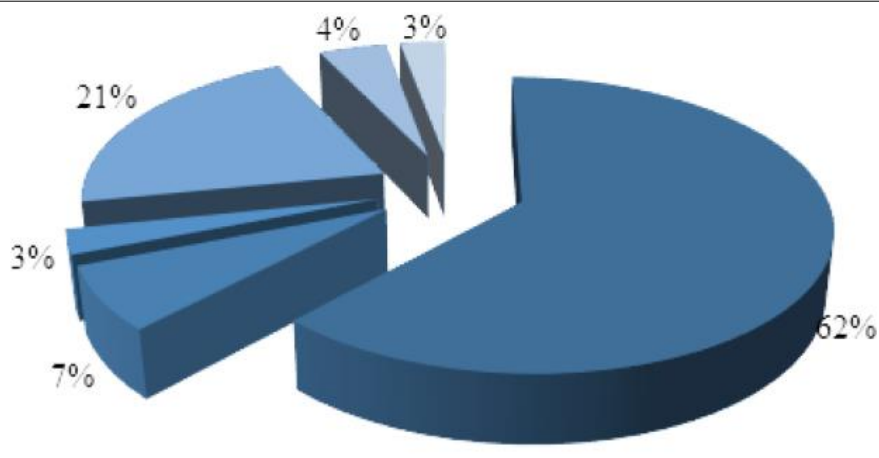

wages

income from entrepreneurial activity and self-employment

income from the sale of agricultural products

pensions, grants, scholarships and subsidies provided in cash

monetary assistance from relatives and other persons

other cash income

\section{Figure 4. Structure of average household cash income for 9 months of 2019}

More than $25 \%$ of the employed persons work in the social infrastructure sectors. Traditionally, the social sphere is financed from the budget. The material basis of the state's participation in the provision of social services depends on the volume of national production and the part of it that is redistributed through the state budget for these purposes.

The study of the dynamics of state budget expenditure in this area provides important information about the priorities of state policy and the imbalance that occur as a result of the distribution of financial resources. For the maintenance and development of health care, education, culture and art institutions, about one third of all budgetary allocations are allocated annually from the state budget. Most of the state expenditures on social payments and benefits are financed under a separate item "Social policy" $(13.9 \%$ of the consolidated budget expenditures $)^{12}$.

${ }^{12}$ Vytraty i resursy domohospodarstv Ukrainy (za danymy vybirkovoho obstezhennia umov zhyttia domohospodarstv Ukrainy) [Expenditures and results of households in Ukraine (according to a sample survey of living conditions of households)]. (2020). State Statistics Service of Ukraine. URL: http://www.ukrstat.gov.ua/operativ/operativ2018/gdvdg/Arh_ vrdu_u.htm 
The share of social expenditure in total general and special budget expenditure in 2020 was in the range of 50\%. Due to the COVID-19 pandemic, there is a reallocation of expenditure within the social sector in 2020 and there has been a reduction in state subsidies for education and culture, and these amounts have been directed towards supporting medicine and increasing the salaries of health care workers.

Overall, the government has reduced funding for the Ministry of Education and Science by almost UAH 3 billion, with total payments amounting to UAH 39 billion, according to the present demands. In addition, the government has cut the payments for the social protection of teachers by UAH 1.55 billion. Support for education, science and sport, which had been earmarked for UAH 500 million by the Presidential Fund, has been withdrawn. In 2020, funding for higher education institutions was reduced by UAH 250 million, research spending was cut by UAH 400 million, funding for the New Ukrainian School project was reduced by UAH 361 million, and there will be a UAH 1 billion reduction for the school capable of better results.

Spending on many other social sectors has also been cut, in particular the Ministry of Culture will receive $50 \%$ of the planned expenditure, around UAH 7 billion, and the Institute of Books will receive only 34\% of the planned expenditure.

\section{CONCLUSION}

In the context of limited budgetary resources, the task of building a market economy with a social orientation is of particular importance in order to improve the living standards of households. The issues of improving the living standards of households do not lose its relevance, since they are the most important component of the economy of a modern country. A significant drop in the material well-being of a large part of Ukraine's population has caused an intense economic stratification of society.

Thus, the problems of improving households' living standards are important today both for the citizens themselves and for the Ukrainian government. The strategic development priorities of Ukraine determine the need for state intervention and regulation of issues related to the improvement of living standards at the national, regional and territorial levels.

Having considered the aforementioned aspects of state social support, we can conclude that, despite the difficult situation in the country and the world, the state is conducting many social programs aimed at developing the social sphere and supporting the population. On the one hand, concern for the welfare of the entire population is a priority of government policy. On the other hand - given the particularities of the benefits and subsidies policy manifested in relation to a large number of citizens, and social payments and social sphere financing exceeding $40 \%$ of GDP, it is difficult to count on 
adequate development of the production segment and to forecast investment growth from domestic sources.

A vicious circle emerges, when socio-economic policy is not aimed at creating conditions that allow economically active citizens to provide a decent standard of living through their own labour, but at freezing the existing condition, when a significant amount of budgetary resources is required to achieve a more or less acceptable standard of living not only for categories of the population who for objective reasons cannot support themselves and therefore need support (disabled, elderly people, large families, etc.), but also of the employable population, most of whom have become socially vulnerable in the current context.

In this regard, the priority of socio-economic policy should be to provide opportunities for the economically active population to increase their income on their own. Of course, it is necessary to support families that are in a difficult financial situation due to the presence of temporarily unemployed people of working age. At the same time, the policy should not generate social dependency - conditions should be created to enable its participants to move later on from being recipients of social assistance to being taxpayers.

\section{SUMMARY}

In the course of the research it was established that the state plays an important role in forming the standard of living of households. The purpose of the research is to reveal the role of the state in improving the standard of living of households and to analyse the current state of the level of state support for the population. The research reveals that the socio-economic development indicators of Ukraine directly affect the standard of living of households. When analysing the level of the Human Development Index, which is one of the main indicators of the standard of living of the population, it has been established that Ukraine occupies the $85^{\text {th }}$ position in the ranking. Having compared the indicators of the leader of the ranking - Norway - with those of Ukraine, a large gap between the indicators of Norway and Ukraine was established; especially it is noticeable in the indicator "Expectation of life at birth". When analysing the poverty rate in Ukraine, it was found that the most vulnerable groups are children aged $0-17$ and pensioners, 29.1 and 31.7 respectively, i. e. every third pensioner and every third child lives in poverty. A study of the state support for households in Ukraine found that about 30 categories of citizens receive social support from the state. The number of persons receiving benefits is almost one third of the total population of Ukraine. It is therefore very important that the state supports not only the socially vulnerable population, but also stimulates the productive sector of the economy. 


\section{REFERENCES}

1. Advokatova, N. (2017). Faktory vplyvu mihratsiyi robochoyi syly Ukrayiny $\mathrm{v}$ umovakh yevropeyskoyi intehratsiyi [Factors influencing labor migration in Ukraine in the context of European integration]. Ekonomichni innovatsiyi: Zbirnyk naukovykh prats, 64, 12-17.

2. Borovik, L. (2018). Analiz vplyvu domohospodarstv naselennia na investytsiinu pryvablyvist haluzi [Analysis of the impact of households on the investment attractiveness of the industry]. Problemy systemnoho pidkhodu $v$ ekonomitsi, 4(66), 33-38.

3. Chervona, S. (2020). COVID-19 ta yoho vplyv na riven zhyttia naselennia Ukrainy [COVID-19 and its impact on the living standards of the population of Ukraine]. Stratehiia rozvytku Ukrainy: finansovo-ekonomichnyi ta humanitarnyi aspekty: materialy VII Mizhnarodnoi naukovo-praktychnoi konferentsii. 400-403.

4. Derzhavne rehuliuvannia rivnia ta yakosti zhyttia naselennia [State regulation of the level and quality of life of the population]. (2020). Biblioteka ekonomista. URL: https://library.if.ua/book/72/5283.html

5. Hetman, A. \& Boyko, L. (2019). Sotsialno-ekonomichni problemy silskykh zhinok na suchasnomu etapi [Socio-economic problems of rural women at the present stage]. Ekonomichnyy rozvytok Ukrayiny $v$ konteksti vprovadzhennya prohresyvnykh informatsiynykh tekhnolohiy ta system upravlinnya: materialy II Vseukr. nauk.-prakt. konf., Kyiv, 214-217.

6. Human Development Report. (2020). Electronic resources Retrieved, December 15, 2020. URL: http://hdr.undp.org/en/content/2020-humandevelopment-report-next-frontier-human-development-and-anthropocene

7. Karnaushenko, A., Petrenko, V., Tanklevska, N., Borovik, L., \& Furdak, M. (2020). Prospects of youth agricultural entrepreneurship in Ukraine. Agricultural and Resource Economics: International Scientific E-Journal, 6(4), 90-117. https://doi.org/10.51599/are.2020.06.04.06

8. Mesto pod solntsem: Top-20 ekonomik mira [A place in the sun: Top 20 economies in the world] (2020). Faktograf. URL: https:// www.factograph.info/a/30825544.html

9. Minimalna zarobitna plata [Minimum wage] (2020). Minfin. URL: https://index.minfin.com.ua/ua/labour/salary/min/

10. Reyting stran mira po urovnyu Valovogo vnutrennego produkta [Rating of countries in the world by the level of Gross Domestic Product] (2020). Humanitarnyy portal. URL: https://gtmarket.ru/ratings/ratingcountries-gdp/rating-countries-gdp-info

11. Sotsialno-ekonomichne stanovyshche domohospodarstv Ukrayiny (za danymy vybirkovoho obstezhennya umov zhyttya domohospodarstv) [Socioeconomic situation of households in Ukraine (according to a sample survey of living conditions of households)]. (2020). State Statistics Service of Ukraine. 
URL: http://www.ukrstat.gov.ua/operativ/operativ2018/gdvdg/Arh_soc_ek_ stan_dom.htm

12. Vytraty i resursy domohospodarstv Ukrainy (za danymy vybirkovoho obstezhennia umov zhyttia domohospodarstv Ukrainy) [Expenditures and resources of households in Ukraine (according to a sample survey of living conditions of households)] (2020). State Statistics Service of Ukraine. URL: http://www.ukrstat.gov.ua/operativ/operativ2018/gdvdg/Arh_vrdu_u.htm

\section{Information about the authors: Karnaushenko Alla Serhiivna, $\mathrm{PhD}$ in Economics,} Senior Lecturer at the Department of Economics and Finance Kherson State Agrarian and Economic University 23, Stritenska str., Kherson, Ukraine, 73006 orcid.org/0000-0003-1813-2792 Petrenko Viktoriia Serhiivna,

Doctor of Economic Sciences, Associate Professor, Associate Professor at the Department of Finance, Accounting and Entrepreneurship Kherson State University

27, Universitetskaya str., Kherson, Ukraine, 73000 orcid.org/0000-0001-8336-7665 